\title{
Sifat Fisikokimia dan Fungsional Pati Buah Aibon (Brugueira gymnorhiza L.)
}

\author{
Zita Letviany Sarungallo*), Budi Santoso, dan Eduard Frasisco Tethool \\ Jurusan Teknologi Pertanian, Fakultas Pertanian dan Teknologi Pertanian (Fapertek), \\ Universitas Negeri Papua (UNIPA), Jl. Gunung Salju Amban Manokwari, Papua Barat 98314.
}

Diterima 27-02-2009 Disetujui 08-09-2009

\begin{abstract}
The aim of this research was to evaluate the physicochemical and functional properties of aibon (Brugueira gymnorhiza L.) starch. Research's results show that the form of aibon starch granule was ellips like kidney, with size of 5-4.5 $\mu \mathrm{m}$, has high amylose content of $32.35 \%$, and gelatinization temperature of $85.5-95^{\circ} \mathrm{C}$. It also has high solubility $\left(7^{\circ} \mathrm{Brix}\right)$ and swelling powered of $14.83 \%$ at $90^{\circ} \mathrm{C}$. Pasting behavior of starch suspension $(6.5 \%$, w/v) shows the initial pasting temperature at $85.5^{\circ} \mathrm{C}$ and peak viscosity $200 \mathrm{BU}$ reached at $93^{\circ} \mathrm{C}$. The wide range of gelatinization temperature makes aibon starch resistant to high heat temperature. Functional characters that make aibon starch important for industrial application are its non-adhesive and un-sticky paste, increasing viscosity while it was heated, unstable gel forming, and low stability to freezing-thawing cycle. Aibon starch also has potential usage for carbohydrate base products that need starch which has heat resistant granule but does not need starch that has high viscosity paste.
\end{abstract}

Keywords: Brugueira gymnorhiza L, functional Properties, physicochemical

\section{PENDAHULUAN}

Buah Brugueira gymnorhiza L. merupakan salah satu sumber makanan pokok penduduk Kampung Sowek, Kabupaten Biak, dan dikenal dengan nama aibon (Wabdaron 2002). Pohon aibon merupakan salah satu spesies penyusun hutan mangrove. sedangkan luas hutan mangrove di Papua 2.943.000 ha atau sekitar $69,2 \%$ dari hutan mangrove Indonesia dengan luas 4.250.000 ha (Hamzah 1993). Yulianti (2004) melaporkan potensi pohon aibon pada hutan mangrove di Distrik Supiori Selatan Kabupaten Supiori seluas \pm 120 ha, dengan potensi buah sebesar $6.228,8 \mathrm{~kg} / \mathrm{ha}$. Buah aibon berbuah 3 kali dalam setahun dengan jangka waktu berbunga sampai waktu panen selama 6 bulan, sehingga buah ini selalu tersedia sepanjang tahun. Walaupun demikian pemanfaatan buah aibon sebagai bahan pangan belum populer di tengah masyarakat, karena kurangnya informasi mengenai pemanfaatan maupun proses pengolahannya.

Selama ini pati yang dimanfaatkan untuk berbagai keperluan pangan maupun non pangan di dunia umumnya berasal dari jagung, kentang, ubi kayu dan gandum, dengan total kebutuhan 25,6 juta ton per tahun (dee Wit et al., 1993). Sementara sampai saat ini

\footnotetext{
*Telp: 08124126554

Email: zlsarungallo@yahoo.com
}

Indonesia diperkirakan mengimpor pati termodifikasi lebih dari 378 ribu ton pertahun dengan nilai kurang lebih 73 juta dolar Amerika Serikat (Anonim 1999). Sarungallo dan Santoso (2007) melaporkan bahwa buah aibon mengandung protein $3,88 \%$, lemak $0,851 \%$, abu $1,24 \%$, serta karbohidrat sebesar $94,03 \%$, dengan kadar pati $67,75 \%$, total gula $4,56 \%$ dan serat kasar $11,48 \%$. Oleh karena itu dengan kandungan karbohidrat dan pati yang cukup tinggi, maka buah aibon berpeluang untuk dikembangkan sebagai sumber pati baru di Indonesia.

Karakterisasi fisikokimia maupun fungsional pati buah aibon sangat diperlukan untuk menentukan proses pengolahan dan produk akhir yang diinginkan (Wirakartakusumah \& Febriyanti 1994) informasi dasar untuk pemanfaatannya lebih lanjut di masa mendatang, serta mengurangi ketergantungan impor pati sebagai bahan baku industri. Penelitian ini bertujuan untuk mengevaluasi sifat fisikokimia dan fungsional pati buah aibon (Brugueira gymnorhiza L.).

\section{BAHAN DAN METODE}

Bahan. Bahan yang digunakan dalam penelitian ini adalah buah aibon (Brugueira gymnorhiza L.) yang diperoleh dari Distrik Supiori Selatan, Kabupaten Supiori, Provinsi Papua. Tapioka dan maizena komersil. 
Bahan untuk analisis antara lain asam asetat, amilosa standar (Merck), amilum, iodine dan aquades.

Ekstraksi Pati Aibon. Ekstraksi pati aibon dilakukan dengan menghacurkan daging buah aibon yang telah dikupas dan direndam larutan asam sitrat 0,01\% dengan blender. Ekstraksi pati menggunakan perbandingan air dan daging buah $3: 1$, dan proses ekstraksi dilakukan sebanyak 6 kali. Untuk mengurangi pengaruh pencoklatan ditambahkan natrium metabisulfit 2000 ppm pada ektraksi pertama, dan dilanjutkan dengan penambahan asam sitrat 0,01\% pada ekstraksi yang ketiga. Pati yang dihasilkan kemudian diendapkan dan dilakukan pencucian sebanyak 6 kali. Pati yang dihasilkan selanjutnya dikeringkan dengan oven pada suhu $60^{\circ} \mathrm{C}$ selama \pm 6 jam (Tjokroadikoesoemo 1986).

Analisis Sifat Fisik dan kimia Pati Aibon. Pengukuran derajat putih pati diukur dengan whiteness meter electric laboratory C-100-3 (Jepang) dengan standar serbuk BaSO4.

Kadar amilosa ditentukan dengan mereaksikan pati $40 \mathrm{mg}$ pati dengan $1 \mathrm{ml}$ etanol $95 \%$ dan $9 \mathrm{ml} \mathrm{NaOH}$ $1 \mathrm{~N}$, lalu dipanaskan 10 menit dan didinginkan. Selanjutnya seluruh campuran dipindahkan ke labu takar $100 \mathrm{ml}$ dan ditepatkan sampai tanda tera dengan aquades. Larutan sampel $5 \mathrm{ml}$ dimasukkan ke dalam labu takar $100 \mathrm{ml}$ dan ditambahkan asam asetat $1 \mathrm{~N}$ $1 \mathrm{ml}$ dan $2 \mathrm{ml}$ larutan lod, lalu ditambahkan aquades sampai tanda tera dan didiamkan selama 20 menit. Intensitas warna biru yang terbentuk diukur dengan spektrofotometer pada panjang gelombang $625 \mathrm{~nm}$. Kadar amilosa dihitung berdasarkan kurva standar (konsentrasi amilosa standar dan absorbansi) (Apriyantono et al., 1989).

Daya pengembangan dan kelarutan pati dilakukan dengan cara memanaskan suspensi pati 2-2,5\% dan dipanaskan dengan magnetic stirrerpada suhu 50, 73, dan $95^{\circ} \mathrm{C}$ kemudian disentrifugasi pada kecepatan 3000rpm selama 15 menit, kemudian kandungan padatan terlarut dalam sentrifugat diamati dengan hand refractometer, sedangkan endapannya dikeringkan pada suhu $105^{\circ} \mathrm{C}$ sampai tercapai berat konstan. Daya pengembangan pati ditentukan dengan cara membagi berat endapan basah dengan berat endapan kering (Kim \& Seib 1993).

Sifat mikroskopik yaitu bentuk dan ukuran granula pati diamati dengan cara meneteskan larutan pati di atas gelas objek kemudian dilihat di bawah mikroskop polarisasi (Olympus BH2) pada perbesaran 200 kali.
Analisis Sifat Fungsional Pati Aibon. Karakterisasi sifat fungsional pati buah aibon dilakukan terhadap suhu gelatinasi, viskositas dan siklus freezethawing. Suhu gelatinasi dan viskositas pati ditentukan menggunakan alat Brabender viscousamilograph dengan cara memanaskan larutan pati $6,5 \%$ (b/v) selama 20 menit sampai suhu mencapai suhu maksimal $\left(93^{\circ} \mathrm{C}\right)$ kemudian diturunkan pada suhu $50^{\circ} \mathrm{C}$ dan dipertahankan selama 20 menit. Sedangkan siklus freeze-thawing dianalisis melalui proses pembekuan gel pati $\left(-16^{\circ} \mathrm{C}\right.$ selama 24 jam) diikuti dengan thawing pada suhu ruang $\left(30^{\circ} \mathrm{C}\right)$, dengan mengukur jumlah air yang keluar dari gel pati sebagai presentasi drip (Hoover \& Manuel 1995). Analisis yang sama juga dilakukan terhadap pati komersil yaitu tapioka dan maizena sebagai pembanding.

Data yang diperoleh dari hasil penelitian ini ditabulasi lalu dianalisis secara deskriptif.

\section{HASIL DAN PEMBAHASAN}

Karakteristik Fisikokimia Pati Aibon. Hasil pengamatan karakteristik fisikokimia pati aibon disajikan pada Tabel 1, beserta karakteristik fisikokimia tapioka dan maizena sebagai pembanding. Gambar buah, irisan buah dan pati dari buah aibon dapat dilihat pada Gambar 1.

Data pada Tabel 1 memperlihatkan bahwa derajat putih pati aibon $98,14 \%$ paling rendah jika dibandingkan dengan derajat putih tapioka $(99,00 \%)$ dan maizena (98,70\%). Namun telah melebihi derajat putih mutu I tapioka berdasarkan SNI tahun 1994 yaitu minimal $94,5 \%$.

Kadar amilosa pati aibon paling tinggi (32,35\%) jika dibandingkan dengan tapioka (14,0\%) dan maizena $(27,0 \%)$. Hal ini menunjukkan bahwa pati aibon cenderung kurang lengket dibandingkan tapioka dan maizena, karena sifat kelengketannya lebih ditentukan oleh kandungan amilopektin. Untuk itu pati aibon tidak cocok diaplikasikan pada industri yang membutuhkan
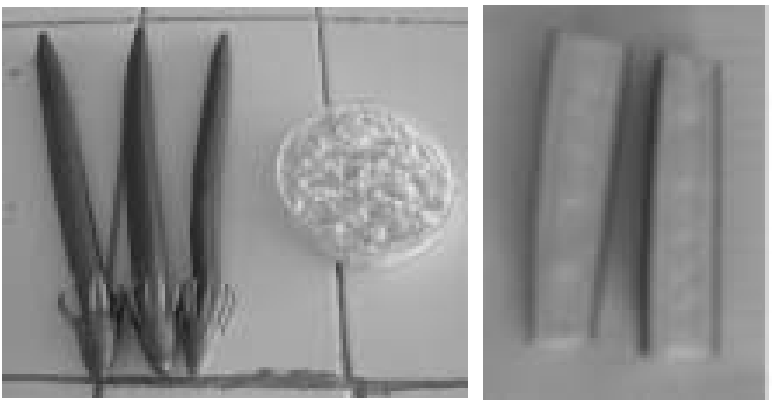

Gambar 1. Buah, pati dan irisan melintang buah aibon 
Tabel 1. Karakteristik Fisikokimia Pati Aibon, Tapioka dan Maizena

\begin{tabular}{|c|c|c|c|}
\hline Karakter Fisikokimia & Aibon & Tapioka & Maizena \\
\hline Derajat putih (\%) & $98,14^{1}$ & $99,0^{3}$ & $98,7^{4}$ \\
\hline Kadar amilosa (\%) & $32,35^{1}$ & $14,00^{2}$ & $27,00^{2}$ \\
\hline Kadar amilopektin (\%) & $67,65^{1}$ & $86,00^{2}$ & $73,00^{2}$ \\
\hline \multicolumn{4}{|c|}{ Daya pengembangan pati, $10 \%$} \\
\hline $55^{\circ} \mathrm{C}$ & $2,83^{1}$ & $16,38^{1}$ & $5,66^{1}$ \\
\hline $75^{\circ} \mathrm{C}$ & $6,89^{1}$ & $18,46^{1}$ & $12,47^{1}$ \\
\hline $90^{\circ} \mathrm{C}$ & $14,83^{1}$ & $18,76^{1}$ & $15,98^{1}$ \\
\hline \multicolumn{4}{|c|}{ Kelarutan pati, $10 \%\left({ }^{\circ}\right.$ Brix $)$} \\
\hline $55^{\circ} \mathrm{C}$ & $0^{1}$ & $0^{1}$ & $0^{1}$ \\
\hline $75^{\circ} \mathrm{C}$ & $0^{1}$ & $1,80^{1}$ & $0,80^{1}$ \\
\hline $90{ }^{\circ} \mathrm{C}$ & $7,00^{1}$ & $5,50^{1}$ & $6,10^{1}$ \\
\hline Bentuk granula & $\begin{array}{c}\text { Bulat lonjong, } \\
\text { menyerupai ginjal }\end{array}$ & Bulat terpotong, elips ${ }^{2}$ & $\begin{array}{c}\text { Hexagonal, bersegi } \\
\text { banyak }^{2}\end{array}$ \\
\hline Ukuran granula $(\mu \mathrm{m})$ & $5-45^{1}$ & $3-40^{2}$ & $5-25^{2}$ \\
\hline
\end{tabular}

${ }^{1}$ Hasil analisa, ${ }^{2}$ Kearsley dan Dziedzic (1995), ${ }^{3}$ Wirakartakusumah dan Febriyanti (1994), ${ }^{4}$ Sivak dan Preiss (1998)

pati dengan kadar amilopektin tinggi terutama untuk industri perekat, sebaliknya lebih cocok diaplikasikan pada industri yang membutuhkan pati dengan kadar amilosa tinggi seperti industri kertas dan tekstil (Sivak \& Preiss 1998).

Selain itu, dengan tingginya kandungan amilosa tersebut maka daya pengembangan pati aibon menjadi lebih rendah dibandingkan dengan tapioka dan maizena (Tabel 1). Semakin tinggi kadar amilosa maka pembentukan gel semakin tidak mudah karena struktur amorf yang terbentuk akan meningkatkan suhu gelatinasi, sehingga daya pengembangannya menjadi rendah. Fenomena yang sama juga terjadi pada pati gayam dengan kadar amilosa tinggi yaitu sekitar $32,72 \%$ (Epriliati 2002). Tingginya kandungan amilosa akan bersifat sebagai inhibitor bagi pengembangan pati (Wirakartakusumah \& Febriyanti 1994; Epriliati 2002). Disamping itu, adanya komposisi kimia yang lain seperti lemak dan protein juga dapat mempengaruhi daya pengembangan pati menjadi lebih rendah.

Daya kelarutan pati aibon paling rendah dibandingkan dengan tapioka $\left(55^{\circ} \mathrm{C}\right)$ dan maizena $\left(75^{\circ} \mathrm{C}\right)$, namun kelarutannya menjadi lebih tinggi pada suhu $90^{\circ} \mathrm{C}$. Hal ini juga dipengaruhi oleh suhu gelatinisasi dan kandungan amilosa pati. Menurut Winarno (1997), amilosa merupakan fraksi pati yang larut dalam air panas dan dapat terbebaskan (leaching) keluar granula ketika tergelatinisasi. Pada kisaran suhu $55^{\circ} \mathrm{C}$ dan $75^{\circ} \mathrm{C}$ pati aibon belum tergelatinasi sehingga amilosa belum dibebaskan, sedangkan tapioka dan maizena umumnya telah tergelatinasi dan fraksi amilosa telah terbebaskan ke medium. Namun pada suhu $90^{\circ} \mathrm{C}$ pati aibon telah tergelatinasi, sehingga dengan kadar amilosa yang lebih tinggi maka jumlah fraksi amilosa yang dibebaskan keluar granula lebih banyak dibandingkan pati lainnya. Akibatnya pada suhu $90^{\circ} \mathrm{C}$, pati aibon memiliki tingkat kelarutan yang lebih tinggi $\left(7,0^{\circ} \mathrm{Briks}\right)$ dibandingkan maizena $\left(6,1^{\circ} \mathrm{Briks}\right)$ dan tapioka $\left(5,5^{\circ}\right.$ Briks $)$.

Bentuk granula pati aibon sangat spesifik dan cenderung berbeda dengan bentuk granula pati umumnya, terutama pati tapioka dan maizena (Tabel 1). Bentuk granula pati juga dipengaruhi oleh letak hilum pada butir granula tersebut (Sutrian 2004). Bentuk granula pati aibon bervariasi dari bulat lonjong (elips) hingga berbentuk menyerupai ginjal, tetapi didominasi oleh bentuk menyerupai ginjal (Gambar 1). Berdasarkan bentuknya, granula pati aibon memiliki letak hilum di tepi (eccentris), sehingga berbentuk lonjong (menyerupai ginjal). Sedangkan granula tapioka dan maizena cenderung memiliki hilum di pusat (centris) sehingga memiliki bentuk berturut-turut bulat dan segi enam (heksagonal).

Ukuran granula pati aibon lebih besar dibandingkan dengan ukuran granula tapioka dan maizena (Tabel 1 dan Gambar 1). Hal ini dapat dilihat dari kisaran ukuran granulanya untuk aibon, tapioka dan maizena yang berturut-turut berkisar antara 5-45 $\mu \mathrm{m}, 3-40 \mu \mathrm{m}$

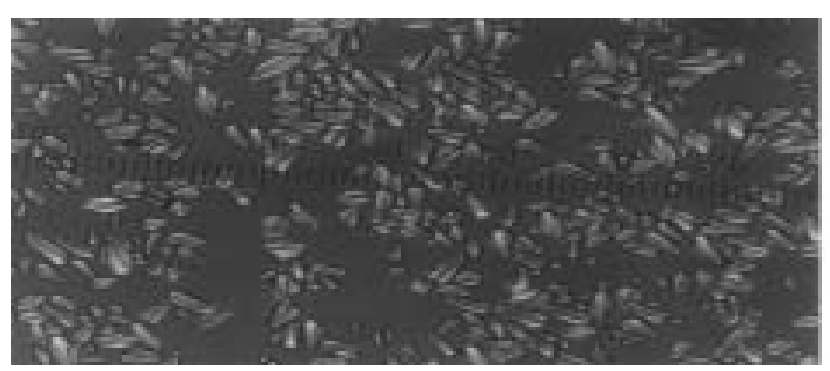

Gambar 2. Granula Pati Aibon, perbesaran 200X 
dan 5-25 $\mu \mathrm{m}$. Hoseney (1998) melaporkan bahwa pada sereal terdapat dua tipe ukuran granula pati, yaitu kecil (5-10 $\mu \mathrm{m})$ dan besar $(25-40 \mu \mathrm{m})$. Lebih besarnya ukuran granula pati aibon dibandingkan kedua jenis pati ini dipengaruhi oleh kandungan amilosa dan amilopektinnya (Tabel 1). Menurut Belitz \& Grosch (1999), fraksi amilosa membentuk bagian amorfgranula dan menyebabkan ukuran granula cenderung besar, namun berbobot molekul tidak terlalu tinggi karena bobot molekul amilosa sekitar $10^{6}$. Sementara rantai cabang amilopektin menyebabkan granula membentuk kristalin dengan ukuran lebih kecil namun berbobot molekul tinggi (antara $10^{7}-7 \times 10^{8}$ ), sehingga ukuran granula pati aibon cenderung lebih besar.

Karakteristik Fungsional Pati Aibon. Gelatinisasi pati biasanya ditandai dengan hilangnya sifat birefrigent atau memantulkan cahaya akibat pembengkakan dan pecahnya granula pati (Winarno 1997). Suhu gelatinasi pati aibon berkisar $85,5-93^{\circ} \mathrm{C}$, lebih tinggi dibandingkan tapioka dan maizena, yang dilaporkan Wirakartakusumah dan Febriyanti (1994) berturut-turut berkisar antara $52-64^{\circ} \mathrm{C}$ dan $62-74^{\circ} \mathrm{C}$.

Bentuk granula pati aibon, tapioka dan maizena pada beberapa suhu pemanasan disajikan pada Gambar 3 , yang menunjukkan bahwa pada suhu kamar granula pati aibon masih utuh dan membentuk birefrigent. Peningkatan suhu pemanasan menjadi $55^{\circ} \mathrm{C}$ menyebabkan pati aibon mulai membengkak, tetapi sebagian besar granulanya masih utuh. Pada suhu $75^{\circ} \mathrm{C}$ sebagian besar granula pati telah mengalami pembengkakan, selanjutnya mengalami gelatinisasi (granula pecah) pada suhu $90^{\circ} \mathrm{C}$, tetapi belum sempurna, yang diindikasikan dengan masih adanya granula yang membengkak. Fenomena ini berbeda dengan perubahan bentuk granula tapioka dan maizena beberapa suhu pemanasan.

Pada suhu kamar, granula tapioka dan maizena masih utuh dan membentuk birefrigent. Pemanasan pada suhu $55^{\circ} \mathrm{C}$ menyebabkan sebagian besar granula tapioka dan maizena telah membengkak, selanjutnya pada suhu $75^{\circ} \mathrm{C}$ seluruh granula pati telah membengkak bahkan sebagian besar telah mengalami gelatinisasi, dan akhirnya tergelatinisasi sempurna pada suhu $90^{\circ} \mathrm{C}$. Kondisi ini menunjukkan bahwa dibandingkan tapioka dan maizena, pati aibon memerlukan suhu yang lebih tinggi untuk mengalami gelatinasi.

Tingginya suhu gelatinasi dapat dipengaruhi oleh ukuran granula, dimana granula pati yang berukuran kecil cenderung memiliki ikatan antar molekul lebih kuat sehingga untuk memutuskan ikatannya tersebut dibutuhkan suhu yang lebih tinggi (Lisisòska \& Leszczyòski 1989). Namun hasil penelitian ini menunjukkan bahwa ukuran granula aibon tergolong besar namun memiliki suhu gelatinasi yang lebih tinggi. Hal ini diduga karena tingginya kandungan amilosa yang didominasi oleh struktur amorf. Lebih lanjut Lisisòska \& Leszczyòski (1989) menjelaskan bahwa untuk memutuskan struktur amorf dibutuhkan energi yang lebih besar dibandingkan memutuskan struktur kristalin, dan gelatinasi mulai terjadi ketika ikatan pada struktur amorf mulai melemah. Winarno (1997) menambahkan bahwa pembengkakan yang diikuti dengan gelatinasi pati terjadi ketika energi kinetik molekul-molekul air menjadi lebih kuat daripada daya tarik menarik antara molekul pati di dalam granula yang menyebabkan air dapat masuk ke dalam granula tersebut.

Selain itu, kandungan protein dan lemak juga berpengaruh pada suhu awal gelatinasi (Wirakartakusumah \& Febriyanti 1994). Semakin tinggi kandungan protein dan lemak yang berinteraksi dengan granula pati, maka suhu awal gelatinisasi patinya juga akan semakin tinggi. Santoso et al., (2006) melaporkan bahwa pati aibon mengandung lemak dan protein berturut-turut $1,05 \%$ dan $0,56 \%$ cenderung lebih tinggi dibandingkan tapioka yaitu masing-masing $0,23 \%$ dan $0,23 \%$ (Kearsley \& Dziedzic 1995), dan maizena yaitu 0,8 dan $0,17 \%$ (Wirakartakusumah \& Febriyanti 1994), sehingga suhu gelatinasi pati aibon lebih tinggi.

Tinggi rendahnya suhu gelatinisasi sangat terkait dengan kebutuhan energi dalam proses pengolahan (Radley 1976). Pati dengan suhu gelatinasi tinggi akan membutuhkan energi dalam jumlah banyak sehingga dinilai kurang efisien. Menurut Winarno (1997) kebutuhan energi dalam proses pengolahan dapat dihemat dengan perlakuan tambahan seperti pengkondisian pati pada $\mathrm{pH}$ tinggi, sehingga pembentukan gel dapat terjadi pada suhu rendah.

Perbandingan data amilogram antara pati aibon dan beberapa pati lainnya dalam perilaku pembentukan pasta disajikan pada Tabel 2. Suhu awal pembentukan pasta pati aibon adalah $85,5^{\circ} \mathrm{C}$ yang dicapai dalam waktu \pm 38 menit, selanjutnya pemanasan pada suhu $93^{\circ} \mathrm{C}$ menghasilkan viskositas $200 \mathrm{BU}$ yang menjadi titik belok (level off) kurva dan jika dipertahankan selama 20 menit terjadi peningkatan viskositas menjadi 
$300 \mathrm{BU}$. Saat dilakukan pendinginan pada suhu $50^{\circ} \mathrm{C}$, terjadi peningkatan viskositas pati menjadi $530 \mathrm{BU}$ dan jika dipertahankan pada suhu tersebut selama 20 menit tidak mengalami perubahan.

Viskositas maksimal (puncak) dari suatu pati merupakan indikator kerusakan granula. Namun dari pengujian pati aibon dengan alat Brabender amilograph ternyata tidak menghasilkan puncak viskositas pada suhu pemanasan tinggi. Hal ini diduga karena pada suhu tersebut granula pati masih ada yang utuh atau belum mengalami kerusakan (Gambar 3). Epriliati (2002) melaporkan bahwa hasil amilogram pati gayam tidak memiliki puncak viskositas, sehingga diduga granula patinya masih utuh. Sedangkan Hustiany et al., (2005) melaporkan viskositas maksimum tapioka yang tergelatinasi sempurna mencapai $1100 \mathrm{BU}$. Fenomena ini tidak terjadi pada sifat amilogram pati lainnya. Umumnya peningkatan suhu menyebabkan granula membengkak sehingga terjadi peningkatan viskositas hingga mencapai puncak yang merupakan indikator kerusakan granula, dan ketika pemanasan dan pengadukan dilanjutkan maka kekuatan granula akan melemah dan struktur pasta terganggu serta pecah sehingga viskositasnya berkurang. Sementara puncak viskositas pati aibon belum tercapai bahkan ketika pemanasan lebih lanjut viskositasnya terus meningkat. Oleh karena itu granula pati aibon tergolong relatif tahan terhadap pemanasan dengan suhu tinggi.

Karakteristik fisik pasta pati terutama didasarkan pada pola pembentukan pasta dan profil perubahan viskositas selama pemanasan. Umumnya pati memiliki karakteristik alir yang spesifik sehubungan dengan sifat fisik dan komposisi kimianya (Radley 1976). Suhu awal pembentukan pasta pati aibon yang tinggi $\left(85,5^{\circ} \mathrm{C}\right)$ mengindikasikan imbibisi oleh air pada granula pati aibon tidak mudah terjadi. Jane et al., (1999) melaporkan bahwa granula pati dengan kandungan amilosa tinggi dan keberadaan kompleks pati lipid/ protein menyebabkan suhu gelatinasi yang tinggi $\left(\geq 100^{\circ} \mathrm{C}\right)$. Oleh karena itu pasta pati aibon pada konsentrasi di bawah $8 \%$ bersifat tidak kental dan tidak lengket. Gel pati aibon terbentuk kokoh sesuai cetakan pada konsentrasi e" $8 \%$, sehingga dalam pengujian stabilitas gel pati terhadap siklus thawing dilakukan pada konsentrasi $8 \%$ dan $10 \%$.

Pengujian stabilitas gel pati aibon dengan konsentrasi $8 \%$ menghasilkan drip sebesar $31,2 \%$, dan pada konsentrasi pati 10\% menghasilkan drip sebesar $24 \%$. Hasil ini lebih tinggi dibandingkan maizena pada konsentrasi $8 \%$ terjadi drip sebesar $14,7 \%$ dan konsentrasi $10 \%$ terjadi drip sebesar $10,2 \%$. Hal ini diduga dipengaruhi oleh kadar amilosa pati aibon $(38,4 \%)$ lebih tinggi dibandingkan maizena $(27 \%)$, sehingga pada waktu dan suhu pembekuan yang sama terjadi drip (sineresis) yang semakin tinggi. Persen drip juga dipengaruhi oleh jumlah siklus dan konsentrasi
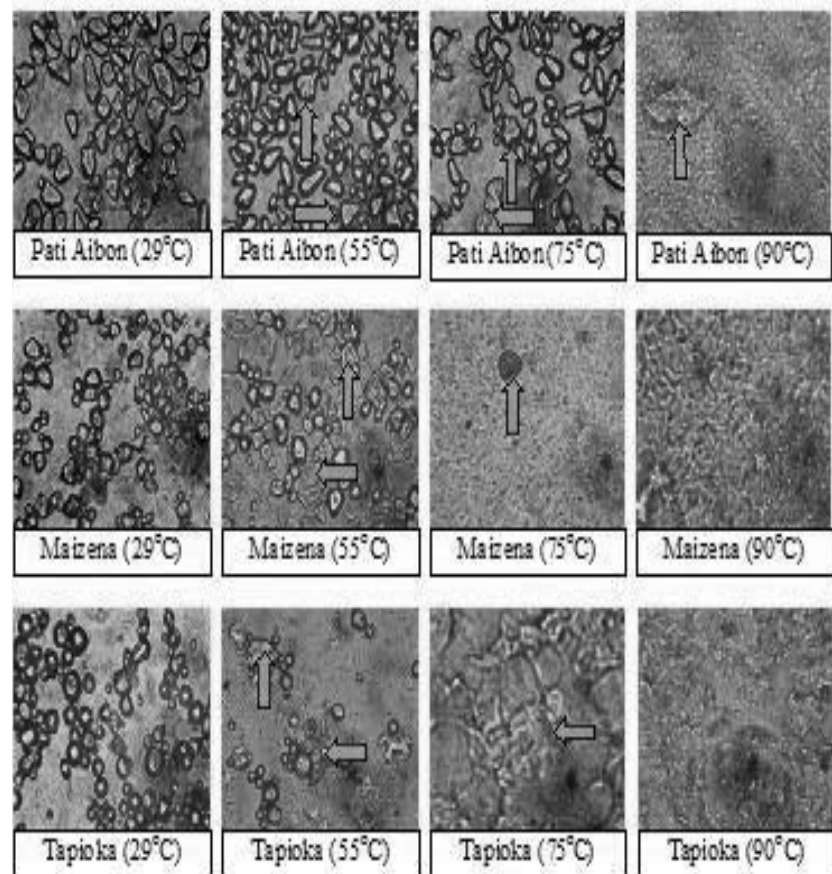

Gambar 3. Bentuk gelatinisasi granula pati aibon, tapioka dan maizena pada beberapa suhu pemanasan. Tanda ( ) menunjukkan granula utuh; tanda ( ) menunjukkan granula membengkak; dan tanda ( ) menunjukkan granula pecah.

Tabel 2. Perbandingan Amilogram Pati Aibon, Tapioka dan Maizena

\begin{tabular}{|c|c|c|c|c|c|c|}
\hline Jenis Pati & $\begin{array}{c}\text { Suhu Awal } \\
\text { Gelatinisasi }\left({ }^{0} \mathrm{C}\right)\end{array}$ & $\begin{array}{c}\text { Suhu } \\
\text { Puncak }\left({ }^{0} \mathrm{C}\right)\end{array}$ & $\begin{array}{c}\text { Viskositas } \\
\text { Puncak (BU) }\end{array}$ & $\begin{array}{c}\text { Viskositas } \\
93^{\circ} \mathrm{C} / 20^{\prime}(\mathrm{BU})\end{array}$ & $\begin{array}{l}\text { Viskositas } \\
50^{\circ} \mathrm{C}(\mathrm{BU})\end{array}$ & $\begin{array}{c}\text { Viskositas } \\
50^{\circ} \mathrm{C} / 20^{\prime}(\mathrm{BU})\end{array}$ \\
\hline Aibon $^{1}$ & 85,5 & 93 & 200 & 300 & 530 & 530 \\
\hline Jagung $^{2}$ & 86,5 & 95 & 380 & & & \\
\hline Ganyam $^{3}$ & 81,0 & 90 & 750 & & & \\
\hline Tapioka ${ }^{4}$ & 65,55 & 75 & 1100 & & & \\
\hline
\end{tabular}

Hasil analisa, konsentrasi pati 6,5\% (b/v), ${ }^{2}$ Sivak \& Preiss (1998), konsentrasi pati 6\% (b/v), Epriliati (2002), konsentrasi pati $10 \%(\mathrm{~b} / \mathrm{v}),{ }^{4}$ Hustiany et al. (2005), konsentrasi pati $10 \%(\mathrm{~b} / \mathrm{v})$ 
Tabel 3. Persentasi Drip Pati Aibon dan Maizena pada Siklus Freezing-Thawing

\begin{tabular}{lcc}
\hline Jenis Pati & Konsentrasi pati (\%) & Drip (\%) \\
\hline \multirow{2}{*}{ Pati Aibon } & 8 & 31,2 \\
& 10 & 24,0 \\
Pati Jagung (Maizena) & 8 & 14,7 \\
& 10 & 10,2 \\
\hline
\end{tabular}

pati. Semakin lama siklus freezing-thawing dilakukan maka kemampuan pasta untuk menahan air semakin rendah, dan dengan semakin tinggi konsentrasi pasta pati maka persen drip semakin rendah. Pati beras ketan dengan kandungan amilopektin yang tinggi memiliki kestabilan freeze-thawyang sangat baik, dimana pasta $5 \%$ pati beras ketan tidak menunjukkan sineresis setelah 20 kali siklus freezing-thawing (Schock 1967 dalam Haryadi 2006). Epriliati (2000) melaporkan bahwa pati gayam dengan kadar apparent amilosa tinggi $(52,7 \%$, bk) mengalami drip sebesar $66,95 \%$ setelah 6 kali freezing-thawing.

Selama pembekuan gel pati aibon maupun maizena membentuk struktur gel berongga, yang dapat mengabsorbsi air secara fisik seperti spons, dan setelah thawing struktur gel tersebut tidak berubah, fenomena ini dapat dilihat dari Gambar 4. Hal ini diduga dipengaruhi tingginya kandungan amilosa kedua jenis pati tersebut sehingga mengalami retrogradasi yang permanen dan membebaskan air, dan menyebabkan kerusakan tekstur gel pati aibon lebih parah dibandingkan maizena. Epriliati (2002) melaporkan bahwa strukur gel pati gayam dengan kandungan amilosa yang tinggi, tidak stabil pada suhu $-16^{\circ} \mathrm{C}$ karena amilosa mengalami retrogradasi secara permanen, sedangkan retrogradasi struktur dari gel tapioka tidak permanen, dan setelah thawing dihasilkan pasta semi cair kembali. Kondisi ini juga yang menyebabkan

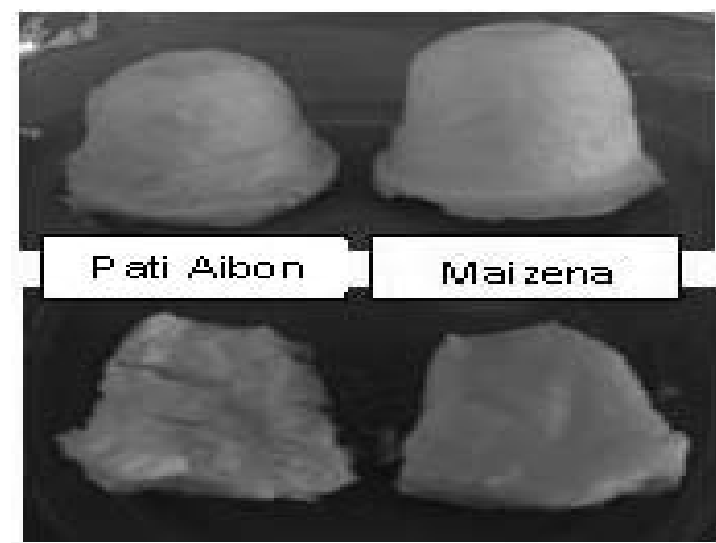

Gambar 4. Gel pasta pati aibon (10\%) dan maizena (10\%) setelah 6 siklus freezing-thawing kemampuan mengikat air dari gel pati aibon semakin menurun, yang terlihat dari susut bobot gel pati aibon selama freezing-thawing, yang diduga karena air tidak dapat terikat lagi secara kimia, tetapi penyerapan air hanya terjadi secara fisik.

\section{KESIMPULAN}

Karakteristik fisikokimia pati aibon adalah memiliki bentuk granula bulat lonjong menyerupai ginjal dengan ukuran 5-4,5 $\mu \mathrm{m}$, mengandung amilosa $32,35 \%$, daya pengembangan pati dan kelarutan pati masing-masing $14,83 \%$ dan $7^{\circ}$ Briks pada suhu $90^{\circ} \mathrm{C}$. Kisaran suhu gelatinasi pati aibon cukup luas yaitu dari $85,5^{\circ} \mathrm{C}-93^{\circ} \mathrm{C}$ dengan viskositas $200 \mathrm{BU}$, sehingga tergolong pati yang tahan terhadap pemanasan tinggi.

Karakter fungsional pati aibon yang penting untuk aplikasi pada industri adalah sifat pasta yang tidak kental, tidak lengket, memiliki viskositas yang cenderung meningkat selama pemanasan, dapat membentuk gel yang tidak terlalu kokoh, dengan stabilitas yang rendah terhadap siklus freezing-thawing. Pati aibon juga berpotensi untuk dimanfaatkan dalam produk-produk berbasis karbohidrat yang memerlukan granula dengan ketahanan panas tinggi tanpa viskositas yang tinggi.

\section{UCAPAN TERIMA KASIH}

Ucapan terima kasih disampaikan kepada Direktorat Pembinaan Penelitian dan Pengabdian Kepada Masyarakat, Direktorat Jenderal Pendidikan Tinggi atas dana yang diberikan melalui Penelitian Dasar dengan Nomor Kontrak 057/SPPP/PP/DP3M/ IV/2005.

\section{DAFTAR PUSTAKA}

Anonim. 1999. Data Impor Indonesia. Jakarta: Biro Pusat Statistik. Apriyantono, A., Fardiaz, D., Puspitasari, N., Sedarwati. \& Budiyanto, S. 1989. Analisis Pangan. Bogor: Pusat Antar Universitas Pangan dan Gizi, Instutut Pertanian Bogor.

Belitz, H.D. \& W. Grocch. 1999. Food Chemistry. $2^{\text {nd }}$ ed. Penterjemah: M.M. Burghahen, D. Hadziyev, P. Hessel, S. Jordan, and C. Spinz. Berlin: Springer-Verlag.

deWit, D., Maat, L. \& Kieboom, A.P.G. 1993. Carbohydrates as Industrial Raw Materials. Industri Crops and Products. London: Elsivier Science Publisher.

Epriliati, I. 2002. Isolasi dan Karakterisasi Sifat Fisik, Kimia, dan Fungsional Pati Gayam (Inocarpus edulis Forst.). Tesis Pasca Sarjana. Bogor: IPB.

Hamzah, Z. 1993. Hutan Mangrove Indonesia. Jakarta: Manggala Wanabhakti.

Haryadi. 2006. Teknologi Pengolahan Beras. Yogyakarta: UGM Press.

Heyne, K. 1987. Tumbuhan Berguna Indonesia III. Jakarta: Litbang Departemen Kehutanan. 
Hoover, R. \& Manuel, H. 1995. A Comparative Study of the Physicochemical Properties of Starces from Two Lentil Cultivars. J. Food Chem. 53: 275-284.

Hoseney, R.C. 1998. Principles of Cereal Science and Technology. $2^{\text {nd }}$ ed. American Association of Cereal Chemists, Minnesota.Inc: St. Paul.

Hustiany, R., Fardiaz, D., Apriyantono, A. \& Andarwulan, N. 2005. Modifikasi Asilasi dan Suksinilasi Pati Tapioka. J. Teknologi dan Industri Pangan. 16: 206-214.

Jane J., Chen, Y.Y., Lee, L. F., McPherson, A. E., Wong, K. S., Radosavljevic, M. \& Kasemsuwan, T. 1999. Effect of amilopectin branch chain length and amylases content on gelatinization and pasting properties of starch. J. Cereal Chemistry. 76: 367-372.

Kearsley, M.W. \& Dziedzic, S.Z. 1995. Handbook of Starch Hydrolysis Products and Their Derivates. London: Blackie Academic and Professional.

Kim W. S. \& Seib, P.A. 1993. Apparent Restriction of Starch Swelling in Cooked Noodles by Lipids in Some Commercial Wheat Flour. J. Cereal Chemistry. 70: 367-372.

Lisisòska, G. \& Leszczyòski, W. 1989. Potato Science and Technology. London: Elsevier Applied Science Ltd.

Radley, J.A. 1976. Examination and Analysis of Starch and Starch products. London: Applied Science Pub, Ltd.

Santoso, B., Sarungallo, Z.L. \& Tethool, E. 2008. Kajian Ekstraksi Pati Aibon (Brugueira gymnorhiza L.). Laporan Penelitian. Manokwari: Lembaga Penelitian Universitas Negeri Papua.
Sarungallo, Z.L. \& Santoso, B. 2007. Sifat Fisik dan Komposisi Kimia Buah Aibon (Brugueira gymnorhiza L.) pada Berbagai Tingkat Kematangan. J. Bionatura. 9: 83-92.

Sivak, M.N. \& Preiss, J. 1998. Starch: Basic Science to Biotechnology. Advances in Food and Nutrition Research Vol. 41. London: Academic Press.

SNI (Standar Nasional Indonesia). 1994. Tapioka. SNI 013451-1994. Jakarta: Dewan Standarisasi Nasional.

Sutrian, Y. 2004. Pengantar Anatomi Tumbuh-Tumbuhan tentang Sel dan Jaringan. Edisi Revisi. Jakarta: PT. Rineka Cipta.

Tjokroadikoesoemo, P.S. 1986. HFS dan Industri Ubi Kayu Lainnya. Jakarta: PT. Gramedia Pustaka Utama.

Yulianti, M. 2004. Potensi Buah Brugueira gymnorrhiza Lamk pada hutan mangrove masyarakat Sowek di Distrik Supiori Selatan. Skripsi Sarjana. Manokwari: Universitas Negeri Papua.

Wabdaron, M.O. 2002. Proses Pengolahan Tradisional Buah Mangrove (Brugueira gymnorrhiza Lamk.) sebagai Bahan Pangan oleh Masyarakat di Kampung Sowek Distrik Supiori Selatan, Kabupaten Biak Numfor. Tugas Akhir Diploma III. Manokwari: Universitas Negeri Papua.

Winarno, F.G. 1997. Kimia Pangan dan Gizi. Jakarta: PT. Gramedia Pustaka Utama.

Wirakartakusumah, M.A. \& Febriyanti, T. 1994. Studi Karakteristik Fisiko Kimia dan Fungsional Tepung Ubi Kayu. Seri Penelitian Pangan Lanjut. 1: 95-110. Bogor: Pusat Antar Universitas Pangan dan Gizi, Instutut Pertanian Bogor. 